\title{
INCREASED TEMPERATURE AND LONG-TERM IMPACT OF THE AGEING PROCESS ON CHANGES IN THE MICROSTRUCTURE OF THE HR6W ALLOY
}

\author{
PODWYŻSZONA TEMPERATURA I DEUGOTRWAEY WPEYW PROCESU \\ STARZENIA NA ZMIANY W MIKROSTRUKTURZE STOPU HR6W
}

The study was carried out to determine the effect of long-term ageing (1,000 and 10,000 hours) at $700^{\circ} \mathrm{C}$ and $750^{\circ} \mathrm{C}$ on the microstructure of the HR6W alloy. The study indicates that the long-term effect of high temperature causes significant changes in the microstructure of the examined alloy:

- After ageing for 1,000 hours at $700^{\circ} \mathrm{C}$, in addition to primary $M X$ and $M_{23} C_{6}$ precipitations, an increase in the size and number of precipitates was observed both inside and along. austenite grain boundaries, and the occurrence of the Laves phase was also observed.

- After 10,000 hours at $700^{\circ} \mathrm{C}$, a significant increase in $M_{23} C_{6}$ precipitates was observed, especially inside and along grain boundaries. An increase in the Laves phase in the microstructure was also observed.

The effect of the increase in the ageing temperature to $750^{\circ} \mathrm{C}$ :

- It significantly accelerated the precipitation process after just 1,000 hours.

- In addition to a network of $M_{23} C_{6}$ precipitates along austenite grain boundaries, their coagulation and an increase in the size of the Laves phase precipitates inside the austenite grains was observed.

- The extension of the ageing time to 10,000 hours at $750^{\circ} \mathrm{C}$ contributed to a significant increase in the size of Laves phase precipitates inside austenite grains.

Keywords: HR6W, microstructure, ageing, precipitates
W pracy przeprowadzono badania, które miaty na celu określenie roptywu dtugotrwatego starzenia (1000 oraz 10 ooo godzin) w temperaturze $700^{\circ} \mathrm{C}$ oraz $750^{\circ} \mathrm{C}$ na mikrostrukture stopu HR6W. Praca wskazuje, że dtugotrwate oddziatywanie roysokiej temperatury powoduje znaczne zmiany w mikrostrukturze badanego stopu:

- Po czasie starzenia 1000 godzin w temperaturze $700^{\circ} \mathrm{Coprócz}$ wydzielen pierwotnych $M X i M_{23} C_{6}$ zaobserwowano wzrost wielkości i ilości wydzieleń zarówno wewnątrz jak i po granicach ziarn austenitu oraz występowanie fazy Lavesa.

- Natomiast po 10000 godzin w temperaturze $700^{\circ} \mathrm{C}$ obserwowano znaczny wzrost roydzieleń $M_{23} C_{6}$, szczególnie weronatrz $i$ po granicach ziarn. Zaobserwowano także zwiększony udziat fazy Lavesa w mikrostrukturze.

Wptyw podreyższenia temperatury starzenia do wartości $750^{\circ} \mathrm{C}$ :

- Spowodowało znaczne przyspieszenie procesu wydzieleniowego już po czasie 1000 godzin.

- Oprócz siatki wydzieleń typu $M_{23} C_{6}$ po granicach ziarn austenitu zaobserwowano ich koagulację oraz wzrost wielkości wydzieleń fazy Lavesa wewnatrz ziarn austenitu.

- Wydtużenie czasu starzenia do 10 ooo godzin w temperaturze $750^{\circ} \mathrm{C}$ przyczynito się natomiast do znacznego wzrostu wielkości wydzieleń fazy Lavesa wewnątrz ziarn austenitu.

Stowa kluczowe: HR6W, mikrostruktura, starzenie, wydzielenia

\section{INTRODUCTION}

In recent years, there has been a demand for higher efficiency of fossil-fuel power stations from the point of view of reducing environmental burden represented by the re-

Corresponding Authors: milena.kierat@polsl.pl adam.zielinski@imz.pl duction of carbon dioxide emissions. The term supercritical parameters refers to power blocks operated in steam conditions at $565-620^{\circ} \mathrm{C}$ and pressure up to $30 \mathrm{MPa}$ and ultra-supercritical (USC) conditions, i.e. $650-720^{\circ} \mathrm{C} / 30-35 \mathrm{MPa}$ with an efficiency of $45-50 \%$.

Advanced ultra-supercritical (A-USC) power stations operating at steam temperatures of $700-760^{\circ} \mathrm{C}$ are the most promising technology to improve the efficiency of fossil-fuel power stations to reduce $\mathrm{CO}_{2}$ emissions: 
- Research teams in Europe and the USA have launched research and development projects regarding A-USC plants and selection of appropriate material technologies [1,2].

- In Japan, advanced heat resisting steels and alloys for USC installations with steam temperatures of $600-650^{\circ} \mathrm{C}$ have been successfully developed [3]; a new A-USC installation project has also been initiated and further innovations in material technology have been introduced based on previously determined alloy designs and application technologies [4-7].

- In Poland, electricity production is still based on coal and lignite, and their significant resources are the primary source of energy $[8,9]$. Unfortunately, this is associated with the negative and continuous emission of pollutants into the atmosphere, including carbon dioxide $\left(\mathrm{CO}_{2}\right)$, sulphur dioxide $\left(\mathrm{SO}_{2}\right)$, nitrogen oxide $\left(\mathrm{NO}_{\mathrm{x}}\right)$ and other types of dust.

To withstand a much higher steam temperature in boilers with USC and A-USC parameters, especially in the final stages of overheating, austenitic steels or nickel alloys are used, which undoubtedly include the HR6W alloy.

\section{MATERIAL FOR TESTING}

The HR6W alloy with a nominal composition of $0.08 \mathrm{C}-23 \mathrm{Cr}-45 \mathrm{Ni}-7 \mathrm{~W}-0.1 \mathrm{Ti}-0.2 \mathrm{Nb}-\mathrm{B}$ was developed taking into account:

- creep strength,

- corrosion resistance,

- stable microstructure at approx. $700-800^{\circ} \mathrm{C}[10-12]$.

This alloy was developed in Japan by Sumitomo Metal Ind. in the late 1980s. It was created as a material for the production of high-strength tubes used for the construction of USC boilers, operating at a steam temperature above $650^{\circ} \mathrm{C}$. It is characterised by an austenitic microstructure with a high content of nickel $(46 \%)$, chromium (23\%), tungsten $(6 \%)$ and additives such as niobium, titanium and boron.

The chemical composition of the HR6W alloy is presented in Table 1 compared to the requirements of the relevant material standards.

$\phi 38 \times 8.8 \mathrm{~mm}$ coil segment made of the as-delivered HR6W (23Cr-45Ni-6W-Nb-Ti-B) alloy, which is shown in Fig. 1, was obtained for testing. Table 1 presents the chemical composition of the tested superheater section in relation to the requirements of the standard.

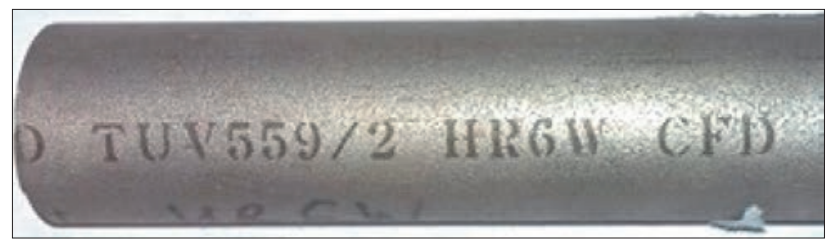

Fig. 1. Section of an HR6W (23Cr-45Ni-6W-Nb-Ti-B) alloy superheater coil

Rys. 1. Wycinek wężownicy przegrzewacza pary ze stopu HR6W (23Cr-45Ni-6W-Nb-Ti-B)

\section{TESTING METHODOLOGY}

The observation of the microstructure of the tested material was performed on metallographic microsections on tubes' cross-sections for the following states:

- as-delivered (after solution heat treatment),

- after ageing at $700^{\circ} \mathrm{C}$ and 1,000 hours,

- after ageing at $700^{\circ} \mathrm{C}$ and 10,000 hours,

- after ageing at $750^{\circ} \mathrm{C}$ and 1,000 hours,

- after ageing at $750^{\circ} \mathrm{C}$ and 10,000 hours,

The microsections were obtained by grinding and polishing followed by electrolytic etching using a $50 \% \mathrm{HNO}_{3}$ solution.

The microstructure was observed using a NEOPHOT 2 light microscope (LM) at magnifications up to $1000 \times$ and using an Inspect F scanning electron microscope (SEM) at magnifications up to $5000 \times$. The chemical composition of the inclusions and precipitates present in the microstructure of the material was analysed using a scanning electron microscope, which is equipped with an EDS detector for the analysis of chemical composition in micro- areas. The chemical composition of the precipitates and their identification was confirmed using a TITAN transmission electron microscope (TEM).

\section{TEST RESULTS}

\subsection{MICROSTRUCTURE OF THE AS-DELIVERED HR6W ALLOY}

The as-delivered HR6W alloy after solution heat treatment has an austenitic microstructure with a small content of primary carbides (Nb,Ti)C. Figure 2a shows the alloy's microstructure observed using a light microscope (LM). Figure $2 \mathrm{~b}$ shows the microstructure observed using a scanning microscope (SEM).

\subsection{MICROSTRUCTURE OF THE HR6W ALLOY AFTER THE AGEING PROCESS}

The image of the observed microstructure of the HR6W alloy after ageing (time $t=1,000$ and 10,000 hours, temperature $T=700^{\circ} \mathrm{C}$ ) differs from the as-delivered microstructure (Fig. 3).

It was shown that the ageing process of the HR6W alloy intensifies the processes of precipitation of secondary phases. In the microstructure along grain boundaries, an increase in the number of and size of $\mathrm{M}_{23} \mathrm{C}_{6}$ precipitates and intermetallic phase $-\mathrm{Fe} 2 \mathrm{~W}$ Laves rich in tungsten was observed. Evenly distributed fine precipitates of $\mathrm{M}_{23} \mathrm{C}_{6}$ and MX carbides were observed inside the HR6W alloy grains. The beginnings of Laves phase precipitations were observed inside the grains in the form of elongated particles $(1,000$ hours), while after a longer time (10,000 hours) a significant increase in the Laves phase inside the grains in the form of elongated particles of irregular shape was observed.

Table 1. Chemical composition of the investigated superheater coil material with reference to the requirements of Vd TüV559/2 09.2011 Tabela 1. Skład chemiczny badanego materiału wężownicy przegrzewacza pary w odniesieniu do wymagań normy Vd TüV559/2 09.2011

\begin{tabular}{|l|c|c|c|c|c|c|c|c|c|c|}
\hline \multirow{2}{*}{ Source of analysis } & \multicolumn{9}{|c|}{ Alloying element [wt \%] } \\
\cline { 2 - 26 } & $\mathbf{C}$ & $\mathbf{S i}$ & $\mathbf{M n}$ & $\mathbf{P}$ & $\mathbf{S}$ & $\mathbf{C r}$ & $\mathbf{W}$ & $\mathbf{T i}$ & $\mathbf{N b}$ & $\mathbf{F e}$ \\
\hline Standard Vd TÜV559/2 09.2011 & 0.10 & 1.0 & 1.50 & 0.030 & 0.015 & $21.5-24.5$ & $6-8$ & 0.20 & 0.35 & $20-30$ \\
\hline Follow-up & 0.09 & 0.95 & 1.32 & 0.005 & 0.003 & 24.15 & 7.95 & 0.18 & 0.29 & rest \\
\hline
\end{tabular}



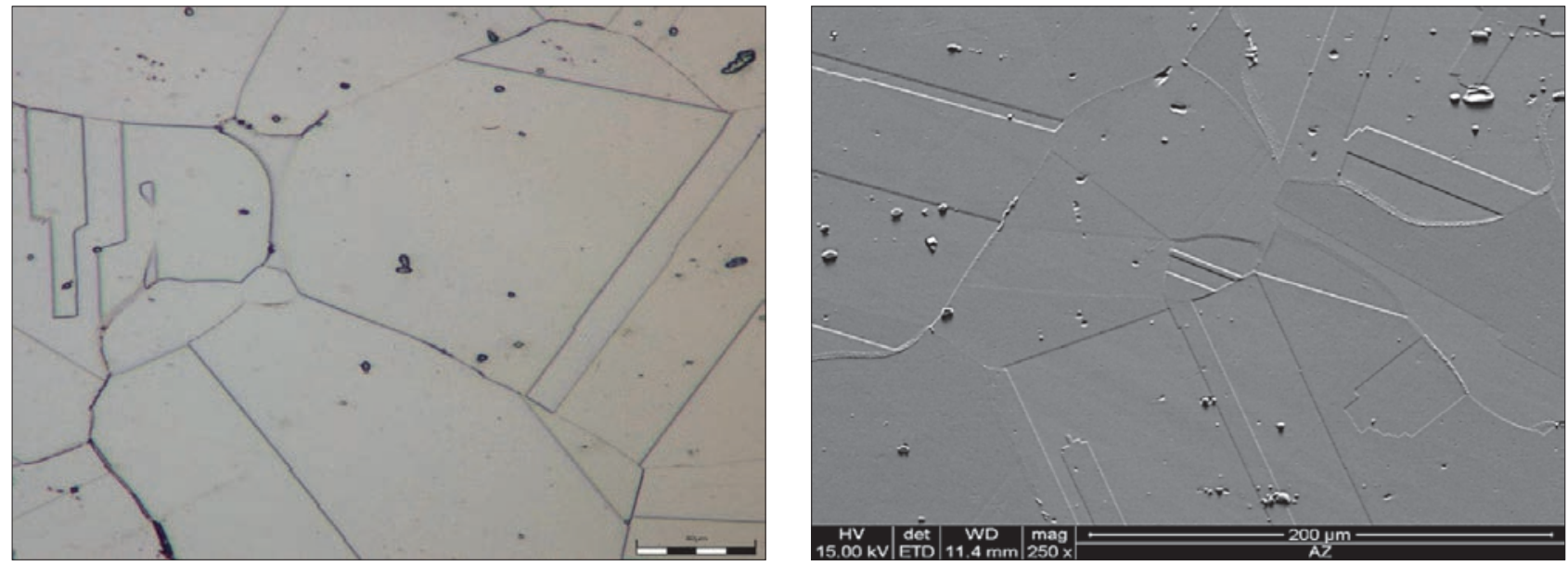

Fig. 2. Microstructure of the as-delivered HR6W alloy (LM) Rys. 2. Mikrostruktura stopu HR6W w stanie dostawy (LM)

as-delivered
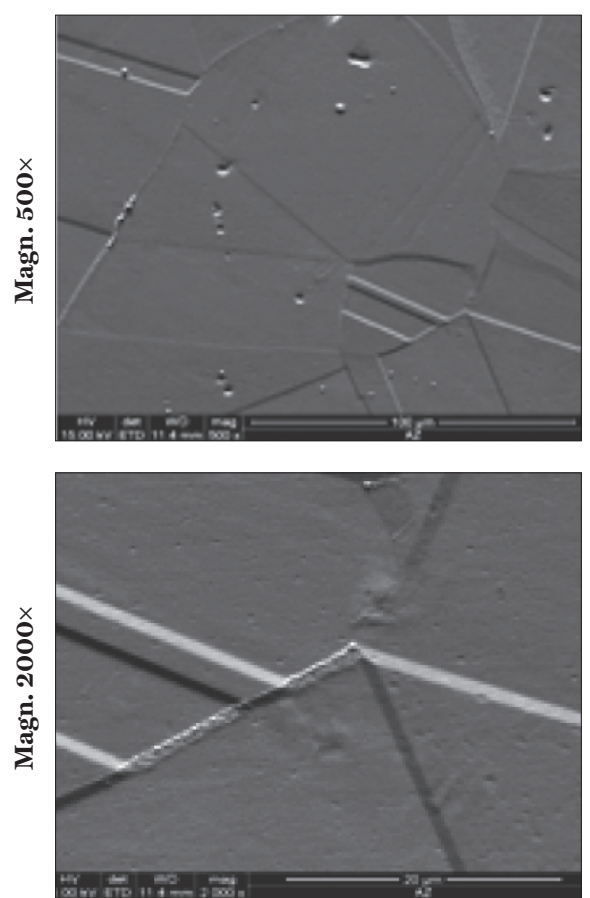

after $1000 \mathrm{~h}$
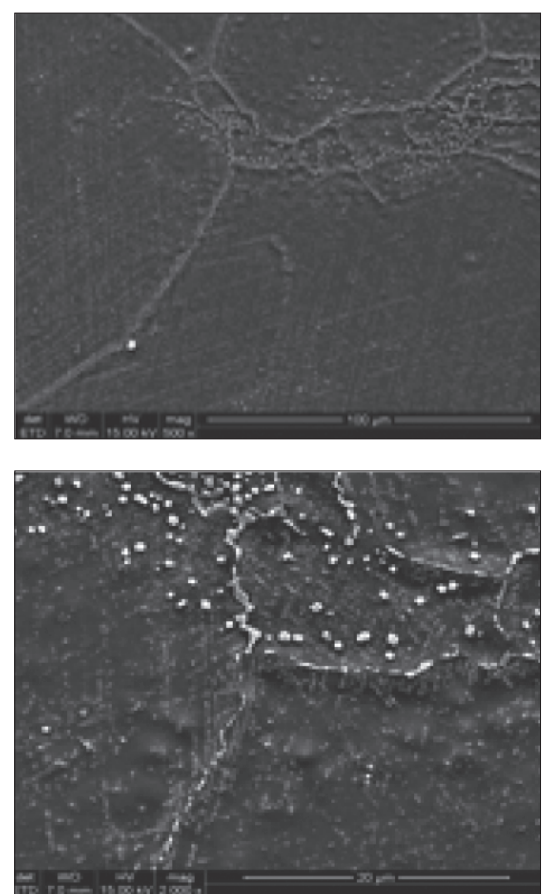

after $10,000 \mathrm{~h}$
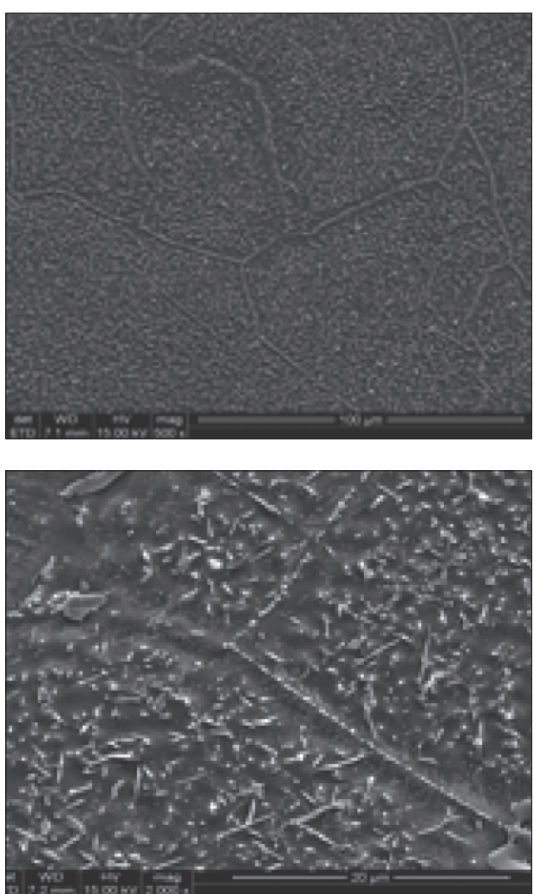

Fig. 3. Comparison of the microstructure of the HR6W alloy as delivered and after ageing at $700^{\circ} \mathrm{C}$

Rys. 3. Porównanie mikrostruktury stopu $\mathrm{HR} 6 \mathrm{~W}$ w stanie dostawy i po starzeniu w temperaturze $700^{\circ} \mathrm{C}$

The increase of the ageing temperature to $750^{\circ} \mathrm{C}$ caused a significant acceleration of the precipitation process after just 1,000 hours. In addition to a network of $\mathrm{M}_{23} \mathrm{C}_{6}$ precipitates along austenite grain boundaries, their coagulation and an increase in the size of the Laves phase precipitates inside the austenite grains was observed. The extension of the ageing time to 10,000 hours at $750^{\circ} \mathrm{C}$ contributed to a significant increase in the size of Laves phase precipitates inside austenite grains (Fig. 4).

After the ageing of the tested material, the microstructure was investigated using light microscopy (LM), scanning electron microscopy (SEM) and transmission electron microscopy (TEM), as shown in Fig. 5-8.

After ageing the $\mathrm{HR} 6 \mathrm{~W}$ alloy at $T=750^{\circ} \mathrm{C}$ and for $t=10,000$ hours, the microstructure was investigated using scanning electron microscopy (SEM) (Fig. 9-10).

\subsection{HARDNESS MEASUREMENT}

The ageing of the HR6W alloy caused an increase in its hardness. The as-delivered alloy's hardness was approx. 181 HV10. After performing individual heat treatment variants, the hardness of the alloy was:

$t=1,000$ hours at $T=700^{\circ} \mathrm{C}-$ hardness: $193 \mathrm{HV} 10$

$t=10,000$ hours at $T=700^{\circ} \mathrm{C}-$ hardness: $205 \mathrm{HV} 10$

$t=1,000$ hours at $T=750^{\circ} \mathrm{C}-$ hardness: $202 \mathrm{HV} 10$

$t=10,000$ hours at $T=750^{\circ} \mathrm{C}-$ hardness: $236 \mathrm{HV} 10$.

The increase in hardness of the examined alloy is associated with the precipitation of secondary phases in its structure. Figure 11 presents a graph showing a summary of the average hardness value of the HR6W alloy from measurements (median calculated from 5 unit measurements). 
as-delivered
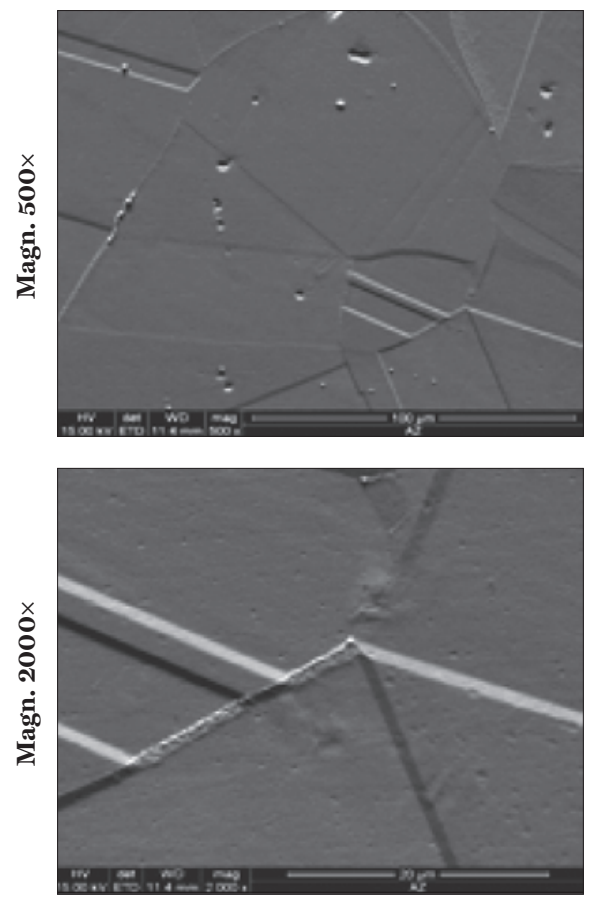

after $1,000 \mathrm{~h}$
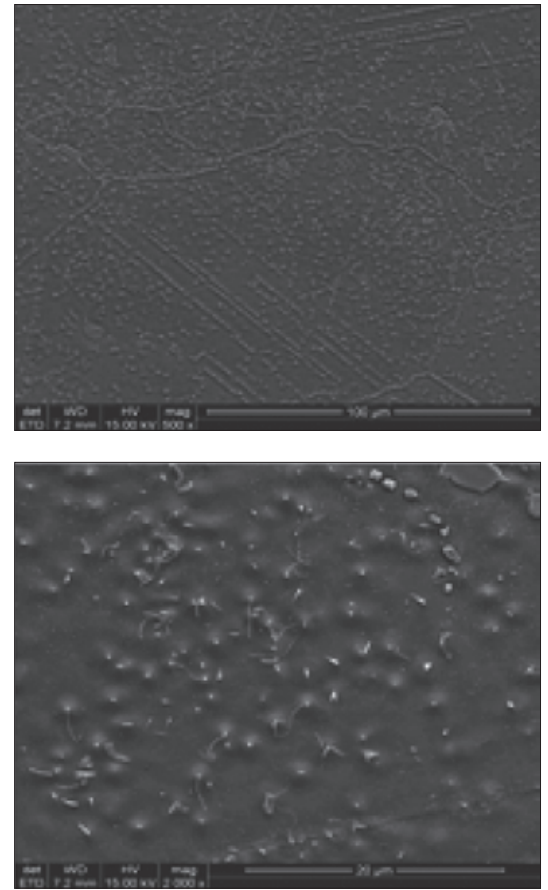

after $10,000 \mathrm{~h}$
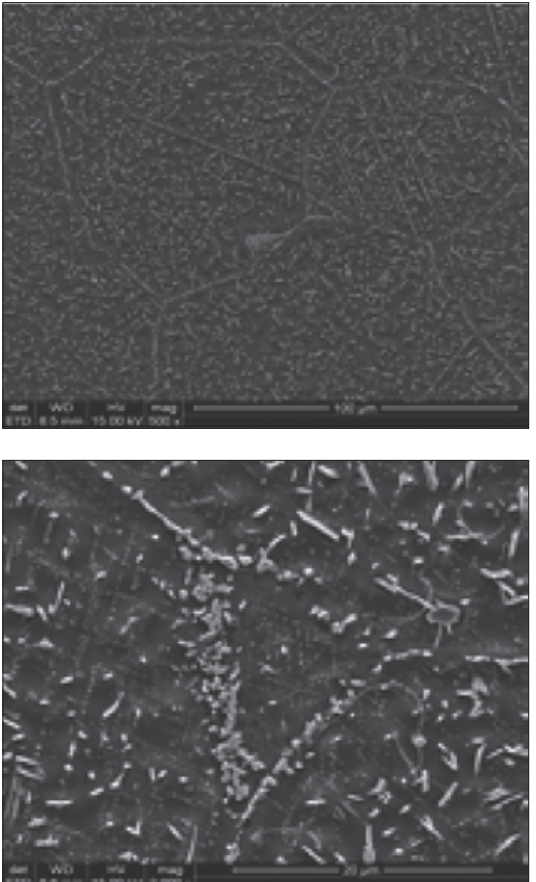

Fig. 4. Comparison of the microstructure of the $\mathrm{HR} 6 \mathrm{~W}$ alloy as delivered and after ageing at $750^{\circ} \mathrm{C}$ Rys. 4. Porównanie mikrostruktury stopu $\mathrm{HR6W}$ w stanie dostawy i po starzeniu w temperaturze $750^{\circ} \mathrm{C}$
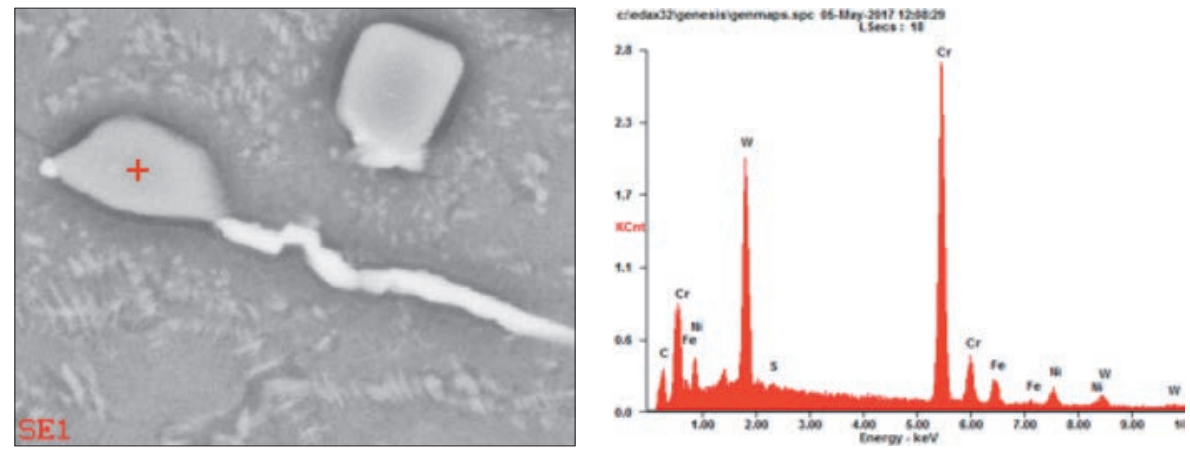

\begin{tabular}{|c|r|r|}
\hline Item & Wt \% & At \% \\
\hline $\boldsymbol{C K}$ & 6.47 & 28.17 \\
\hline $\boldsymbol{W M}$ & 29.49 & 8.39 \\
\hline $\boldsymbol{S K}$ & 0.23 & 0.38 \\
\hline $\boldsymbol{C r K}$ & 51.15 & 51.48 \\
\hline $\boldsymbol{F e K}$ & 6.36 & 5.96 \\
\hline $\boldsymbol{N i K}$ & 6.30 & 5.62 \\
\hline
\end{tabular}

Fig. 5. Analysis of the chemical composition of the $\left.\mathrm{M}_{23} \mathrm{C}_{6}(\mathrm{Cr}, \mathrm{Fe}, \mathrm{W})_{23} \mathrm{C}_{6}\right)$ precipitate in the $\mathrm{HR} 6 \mathrm{~W}$ alloy after ageing for 1,000 hours at $700^{\circ} \mathrm{C}$ Rys. 5. Analiza składu chemicznego wydzielenia typu $\left.\mathrm{M}_{23} \mathrm{C}_{6}(\mathrm{Cr}, \mathrm{Fe}, \mathrm{W})_{23} \mathrm{C}_{6}\right) \mathrm{w}$ stopie $\mathrm{HR} 6 \mathrm{~W}$ po starzeniu przez 1000 godzin w temperaturze $700^{\circ} \mathrm{C}$
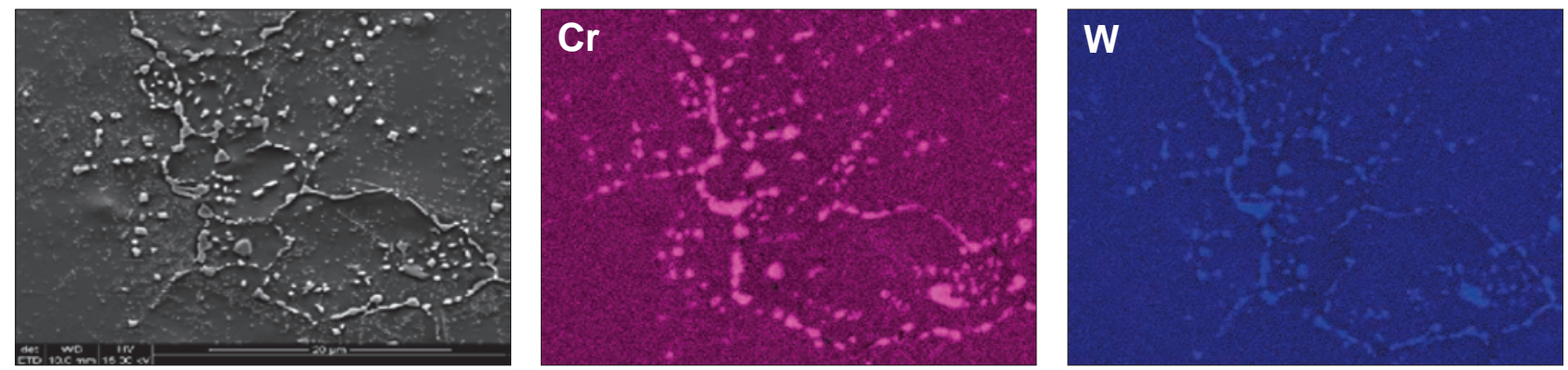

Fig. 6. Distribution of chromium and tungsten concentration in the microstructure of the $\mathrm{HR} 6 \mathrm{~W}$ alloy after ageing at $700^{\circ} \mathrm{C}$ for 1,000 hours. SEM observation (map of precipitates)

Rys. 6. Rozkład stężenia chromu i wolframu w mikrostrukturze stopu HR6W po starzeniu w temperaturze $700^{\circ} \mathrm{C}$ przez 1000 godzin. Obserwacja SEM (mapa wydzieleń) 

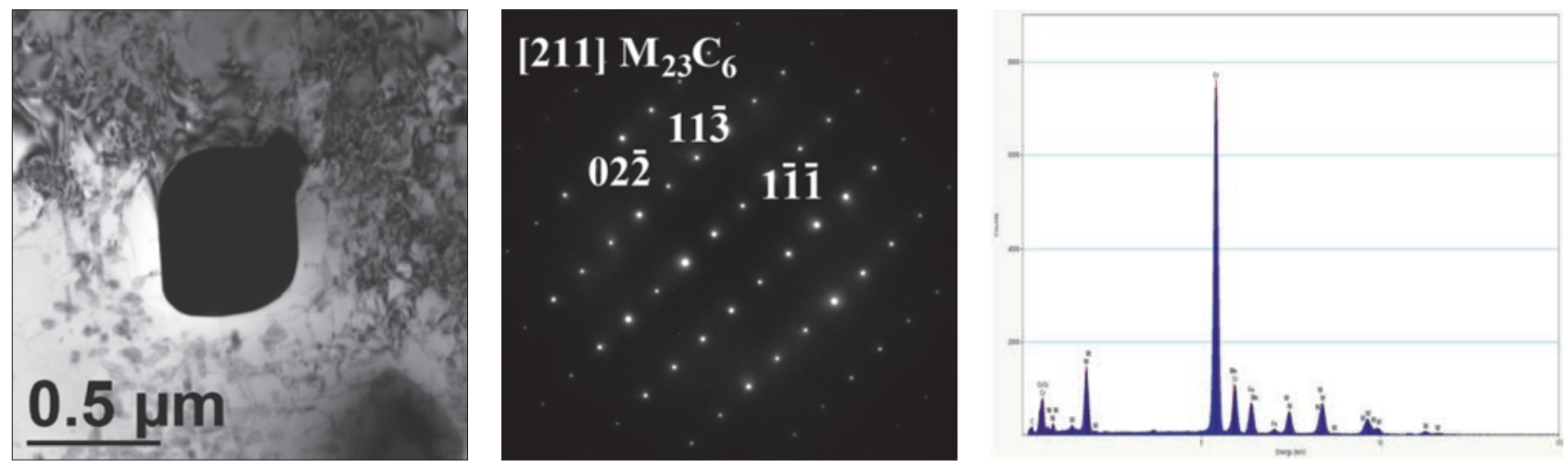

Fig. 7. Identification of the $\mathrm{M}_{23} \mathrm{C}_{6}$ precipitate in the $\mathrm{HR6W}$ alloy after ageing for 1,000 hours at $700^{\circ} \mathrm{C}(\mathrm{TEM})$

Rys. 7. Identyfikacja wydzielenia typu $\mathrm{M}_{23} \mathrm{C}_{6} \mathrm{w}$ stopie $\mathrm{HR} 6 \mathrm{~W}$ po starzeniu przez 1000 godzin w temperaturze $700^{\circ} \mathrm{C}(\mathrm{TEM})$
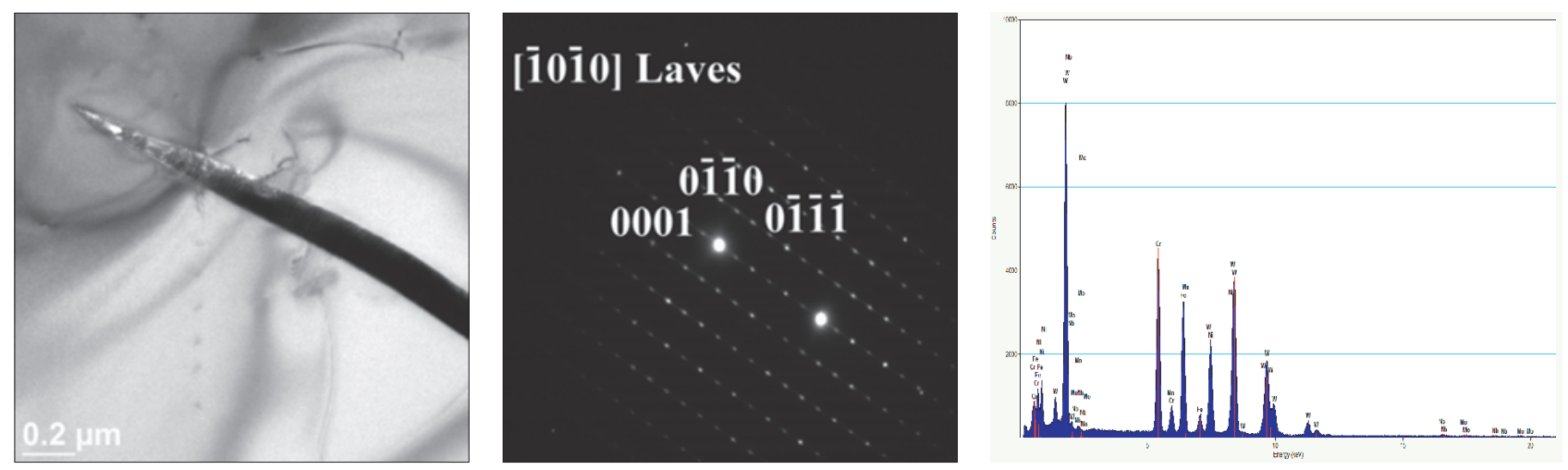

Fig. 8. Identification of the Laves phase precipitate in the $\mathrm{HR} 6 \mathrm{~W}$ alloy after ageing for 1,000 hours at $700^{\circ} \mathrm{C}(\mathrm{TEM})$

Rys. 8. Identyfikacja wydzielenia typu faza Lavesa w stopie $\mathrm{HR} 6 \mathrm{~W}$ po starzeniu przez 1000 godzin w temperaturze w temperaturze $700^{\circ} \mathrm{C}\left(\mathrm{TEM}^{\mathrm{C}}\right)$
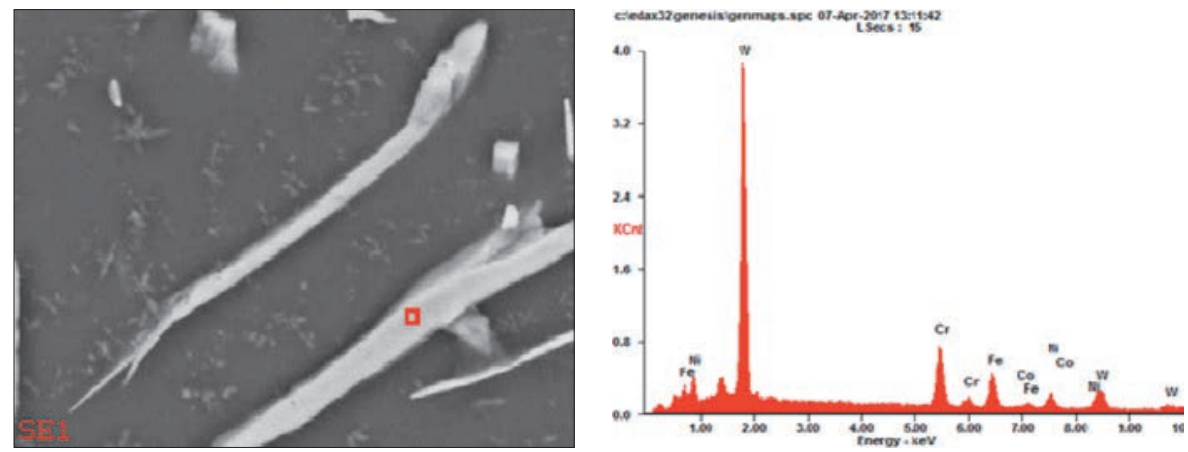

\begin{tabular}{|c|c|c|}
\hline Item & Wt \% & At \% \\
\hline $\boldsymbol{W}$ & 68.39 & 39.16 \\
\hline $\boldsymbol{C o}$ & 0.00 & 0.00 \\
\hline $\boldsymbol{C r}$ & 13.58 & 27.50 \\
\hline $\boldsymbol{F e}$ & 10.90 & 20.55 \\
\hline $\boldsymbol{N} \boldsymbol{i}$ & 7.13 & 12.78 \\
\hline
\end{tabular}

Fig. 9. Analysis of the chemical composition of the Laves phase precipitate in the $\mathrm{HR} 6 \mathrm{~W}$ alloy after ageing for 10,000 hours at $750^{\circ} \mathrm{C}$ Rys. 9. Analiza składu chemicznego wydzielenia typu faza Lavesa w stopie $\mathrm{HR} 6 \mathrm{~W}$ po starzeniu przez 10000 godzin w temperaturze $750^{\circ} \mathrm{C}$
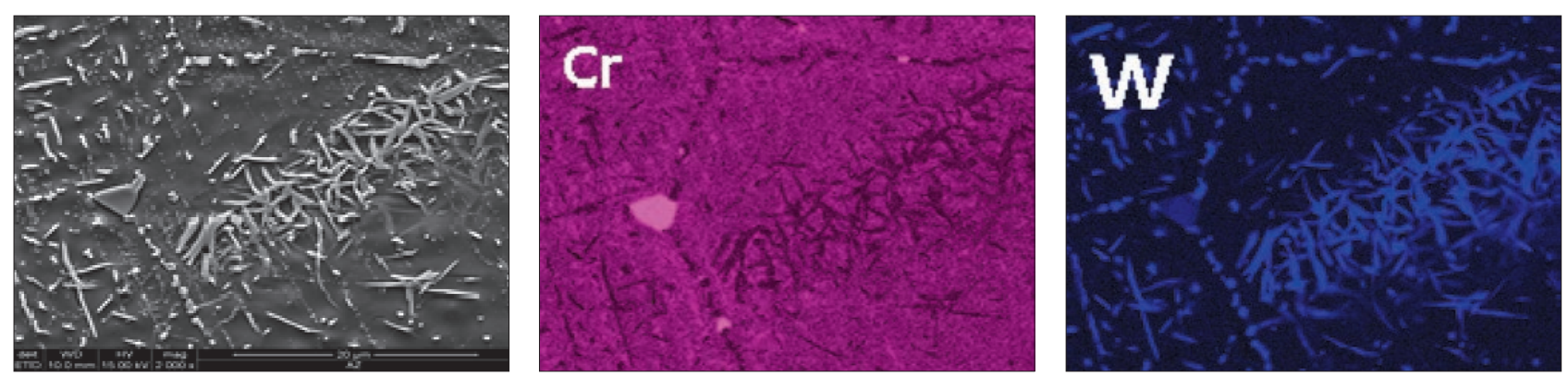

Fig. 10. Distribution of chromium and tungsten concentration in the microstructure of the $\mathrm{HR} 6 \mathrm{~W}$ alloy after ageing at $750^{\circ} \mathrm{C}$ for 10,000 hours. SEM observation (map of precipitates)

Rys. 10. Rozkład stężenia chromu i wolframu w mikrostrukturze stopu HR6W po starzeniu w temperaturze $750^{\circ} \mathrm{C}$ przez 10000 godzin. Obserwacja SEM (mapa wydzieleń) 


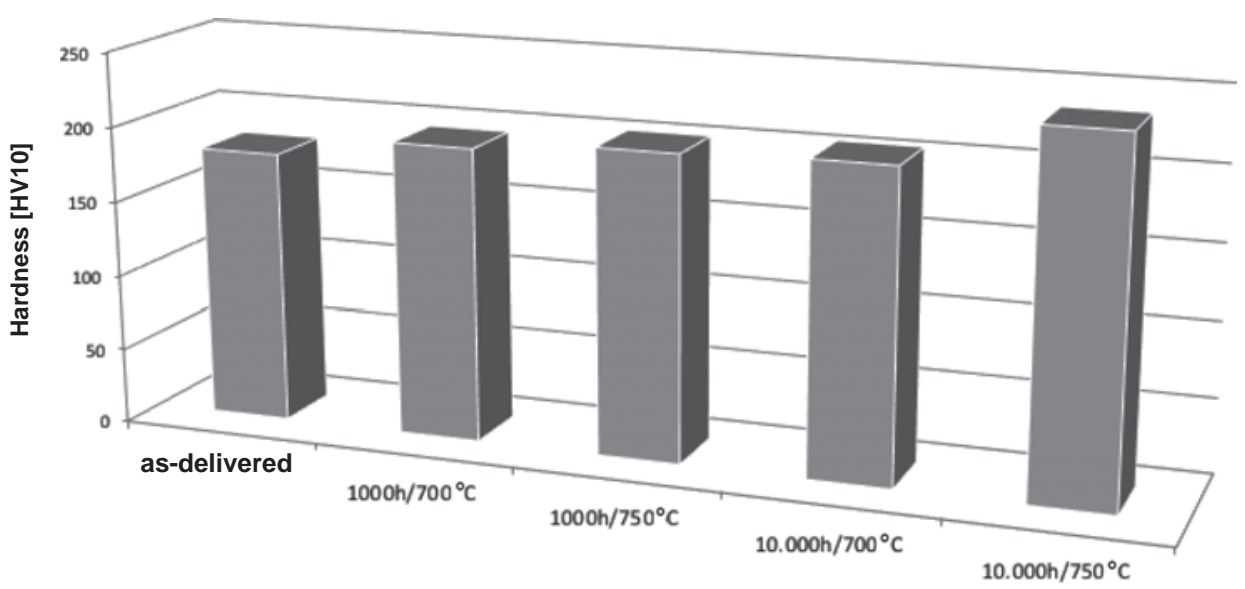

Fig. 11. Graph showing a summary of the average hardness value of the HR6W alloy from measurements (median calculated from 5 unit measurements)

Rys. 11. Wykres pokazuje zestawienie średniej wartości twardości stopu HR6W z przeprowadzonych pomiarów (średnia wyliczona z 5 pomiarów jednostkowych)

\section{CONCLUSIONS}

Based on the carried out research and analysis, the following conclusions can be drawn:

In the state after solution heat treatment, the HR6W alloy has a coarse-grained structure with small primary MX precipitates and $\mathrm{M}_{23} \mathrm{C}_{6}$ carbides.

The increase of the ageing temperature to $750^{\circ} \mathrm{C}$ caused a significant acceleration of the precipitation process after just 1,000 hours. The extension of the ageing time to 10,000 hours at $750^{\circ} \mathrm{C}$ contributed to a significant increase in the size of Laves phase precipitates inside austenite grains.

The use of transmission electron microscopy (TEM) after ageing for 1,000 hours at $750^{\circ} \mathrm{C}$ enabled the identification of
$\mathrm{M}_{23} \mathrm{C}_{6}$ precipitates in the HR6W alloy, as well as the Fe2W Laves phase inside austenite grains.

The measured hardness of the as-delivered HR6W alloy was at the level of $181 \mathrm{HV10}$. It increased to 193 and 205 HV10 after the ageing rate of 1,000 and 10,000 hours respectively at $700^{\circ} \mathrm{C}$. Similarly, an increase in hardness was observed after ageing at $750^{\circ} \mathrm{C}$ - it was, respectively, for 1,000 and 10,000 hours: 202 and 236 HV10.

The observed increase in hardness depending on the temperature and ageing time indicates the rate of changes in the microstructure of the HR6W alloy as a result of the precipitation of secondary phases. This, in turn, will probably have an impact on the decrease in its plasticity, deteriorating its performance.

\section{REFERENCES}

[1] R. Blum, R.W. Vanstone. Materials development for boilers and steam turbines operating at $700^{\circ} \mathrm{C}$. In: 8th Liège Conference on Materials for Advanced Power Engineering. Liège, 2006, p. 41-60.

[2] R. Viswanathan, R. Purgert. U.S. Program on Materials Technology for Ultrasupercritical Coal-Fired Steam Power Plants. In: 8th International Conference on Creep and Fatigue at Elevated Temperatures. San Antonio, Texas, USA, July 22-26, 2007, p. 57-71.

[3] F. Masuyama. Advanced power plant developments and material experiences in Japan. In: 8th Liège Conference on Materials for Advanced Power Engineering. Liège, 2006, p. 175-187.

[4] J. Iwasaki, A. Shiibashi, S. Takano, T. Sato, H. Okada, F. Abe. (tytuł ??) The Thermal and Nuclear Power, 2007, 58, p. 649-655.

[5] T. Fujikawa, M. Fukuda, E. Saito, T. Takahashi, S. Izumi. The Thermal and Nuclear Power, 2007, 58, p. 656-662.

[6] M. Fukuda. Current Advances in Materials and Processes. The Iron and Steel Institute of Japan, 2008, 21, p. 1018-1021.

[7] http://www.enecho.meti.go.jp/info/tender/tenddata/0806/ 080626a/1.pdf.
[8]J. Brózda. Stale żarowytrzymałe nowej generacji, ich spawalność i własności złączy spawanych. Część I. Cel stosowania stali żarowytrzymałych nowej generacji, ich charakterystyka i wynikające korzyści. Biuletyn Instytutu Spawalnictwa w Gliwicach, 2004, 48 (1), p. 41-49.

[9] J. Dobrzański. Materials science interpretation of the life of steels for power plants. Open Access Library, 2011, 3, p. 7-14.

[10]Y. Sawaragi, Y. Hayase, Y. Yoshikawa. Development of an austenitic alloy with high elevated temperature strength and superior corrosion resistance for superheater tubings of ultra super critical boilers. In: International Conference on Stainless Steels, ISIJ, Chiba, 1991, p. 633-639.

[11] H. Semba, M. Igarashi, Y. Yamadera, A. Iseda, Y. Sawaragi. Report of the 123rd Committee on Heat-Resisting Materials and Alloys, JSPS, 44 (2003), p. 119-127.

[12] M. Igarashi, H. Semba and H. Okada. In: 8th Workshop on the Innovative Structural Materials for Infrastructure in 21st Century. NIMS, Tsukuba, Japan, 2004, p. 194-199. 